\title{
Human Papillomaviruses Target the DNA Damage Repair and Innate Immune Response Pathways to Allow for Persistent Infection
}

\author{
Elona Gusho $\mathbb{1}$ and Laimonis Laimins *(1) \\ Department of Microbiology-Immunology, Feinberg School of Medicine, Northwestern University, \\ Chicago, IL 60611, USA; elona.gusho@northwestern.edu \\ * Correspondence: 1-laimins@northwestern.edu
}

check for updates

Citation: Gusho, E.; Laimins, L. Human Papillomaviruses Target the DNA Damage Repair and Innate Immune Response Pathways to Allow for Persistent Infection. Viruses 2021, 13, 1390. https://doi.org/ $10.3390 /$ v13071390

Academic Editors: Thomas Iftner and Frank Stubenrauch

Received: 29 June 2021

Accepted: 15 July 2021

Published: 17 July 2021

Publisher's Note: MDPI stays neutral with regard to jurisdictional claims in published maps and institutional affiliations.

Copyright: (c) 2021 by the authors. Licensee MDPI, Basel, Switzerland. This article is an open access article distributed under the terms and conditions of the Creative Commons Attribution (CC BY) license (https:// creativecommons.org/licenses/by/ $4.0 /)$.

\begin{abstract}
Persistent infection with high-risk human papillomaviruses (HPVs) is the major risk factor associated with development of anogenital and oropharyngeal cancers. Initial infection by HPVs occurs into basal epithelial cells where viral genomes are established as nuclear episomes and persist until cleared by the immune response. Productive replication or amplification occurs upon differentiation and is dependent upon activation of the ataxia-telangiectasia mutated (ATM), ataxia telangiectasia and RAD3-related (ATR) DNA damage repair (DDR) pathways. In addition to activating DDR pathways, HPVs must escape innate immune surveillance mechanisms by antagonizing sensors, adaptors, interferons and antiviral gene expression. Both DDR and innate immune pathways are key host mechanisms that crosstalk with each other to maintain homeostasis of cells persistently infected with HPVs. Interestingly, it is still not fully understood why some HPV infections get cleared while others do not. Targeting of these two processes with antiviral therapies may provide opportunities for treatment of cancers caused by high-risk HPVs.
\end{abstract}

Keywords: DNA damage; innate immunity; HPVs; epithelial differentiation; DAMPs

\section{Introduction}

Human papillomaviruses (HPVs) are important pathogens that are the causative agents of many anogenital as well as oral cancers [1]. Over 400 types of HPVs have been identified, and each infects stratified epithelia at different body locations. The viral types are denoted with a number according to the order of their discovery and generate a range of epithelial lesions. HPV type 1 infects epithelia in the soles of feet and causes plantar or palmar warts, while cutaneous HPVs (e.g., HPV 5) are responsible for warts on hands. About one-third of HPV types infect the genital epithelia and are classified as high and low risk according to their propensity to be associated with human cancers. At least 10 types are designated high risk and are the causative agents of over $98 \%$ of cervical cancers as well as those of the anus and vulva [2]. HPV16 is associated with approximately 50\% of cases of cervical cancer, while HPV18 is detected in about 25\% [1]. The remaining eight types are found in less than $5 \%$ each. In western countries, approximately $60 \%$ of oropharyngeal cancers are caused by HPV infection, and these are almost exclusively HPV16 positive [3]. Cases of oropharyngeal cancers are increasing at a rapid pace and likely will soon exceed those of cervical cancer. HPV-induced cancers typically take several decades to develop but can also regress spontaneously through activation of immune recognition. Low-risk HPVs also infect the genital epithelia (e.g., HPV 6, 11) but are rarely associated with cancer [4]. The incidence of HPV-induced cancers will decrease with time due to the development of prophylactic vaccines; however, these only block initial infection and have no effect on existing infections, which may still be able to progress to cancers. A need, therefore, exists to develop antivirals to treat cancers that develop in individuals, who are persistently infected. 


\section{Genome Organization and Viral Proteins}

HPV virions consist of an outer icosahedral shell that encapsidates its $7.9 \mathrm{~kb}$ circular double-stranded DNA genome that is bound by cellular histones. HPVs infect cells in the basal layer of stratified epithelia that become exposed by wounding. Following entry, viral genomes are established as nuclear episomes at about 100 copies per cell. These infected basal cells can persist until they are cleared by the immune system or progress to cancers that are often associated with the integration of viral DNAs into host chromosomes. In productive lesions, the synthesis of progeny virions, however, occurs in highly differentiated suprabasal cells $[5,6]$.

HPV genomes consist of two major coding regions along with a third regulatory region referred to alternatively as the upstream regulatory region (URR) or the long control region (LCR) (Figure 1). The early genes (E) are expressed prior to productive viral replication in suprabasal layers. About 5 to 8 early open reading frames are present in almost all HPV types and are expressed from polycistronic messages that primarily originate from a promoter upstream of the E6 ORF. Interestingly no monocistronic messages have been identified for HPVs indicating alternative splicing is a major regulator of viral expression. E6 and E7 act as viral oncoproteins, while E1 and E2 are replication proteins [7-10]. The E4 and E5 open reading frames are present in the early transcripts but are synthesized at high levels only following differentiation indicating that their primary function is during the late phase of the viral life cycle [11-13].

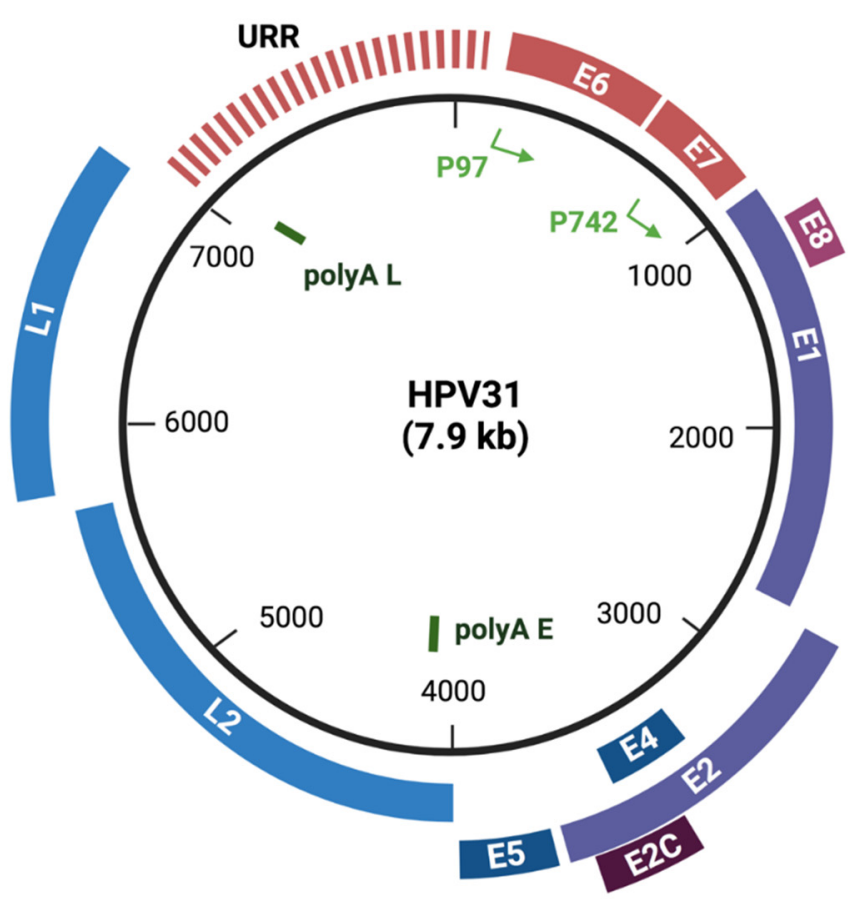

Figure 1. HPV genome structure map of high-risk HPV31. Viral genomes consist of two main coding regions: early (E) and late (L). The early (E) transcripts are initiated at the p97 promoter and are expressed in the lower portion of stratified epithelia. The E6 and E7 open reading frames encode oncogenes that target p53 and Rb, respectively, as well as other cellular proteins. E1 and E2 are the two replication proteins, while E4 and E5 function in the later stages of viral life cycle in suprabasal cells. E8^E2C is a repressor generated by splicing that regulates copy number. Late (L) gene transcription initiates upon differentiation from the p742 promoter and expresses high levels of E1^E4 as well as E5 along with the capsid proteins L1 and L2. The URR is a noncoding region harboring the origin of viral replication and enhancers to regulate viral promoters. HPV31 genome organization is similar to that of other high-risk HPVs such as HPV16 and 18. (Created with BioRender.com, 24 June 2021). 
The E6 proteins are approximately 100 amino acids in size and are localized in both the cytoplasmic as well as nuclear compartments. The high-risk E6 proteins interact with a series of cellular factors that contribute to cellular transformation. The most prominent of these is ubiquitin ligase UBE3A (E6AP), which recruits p53 resulting in its rapid turnover [14,15]. High-risk E6 proteins also activate the catalytic subunit of telomerase, hTert, leading to its activation [16-19]. The extreme C-terminus of high-risk E6 proteins contain PDZ interaction domains, which allow for the binding of factors such as Scribble and DLG that are also important for transformation [20-22]. Low-risk E6 proteins do not induce degradation of p53 and instead interact with the MAML1 protein [23,24].

The E7 proteins are found primarily in the nucleus and bind to members of the $\mathrm{Rb}$ family of proteins. Binding of high-risk $\mathrm{E} 7$ protein induces degradation of $\mathrm{Rb}$ leading to constitutive activation of E2F family members, resulting in rapid entry into S-phase [25-28]. Low-risk E7 proteins also bind to RB proteins but with a significantly reduced affinity [29]. E7 proteins bind to p600 as well as HDACs among other factors [30-32].

The E1 proteins bind to HPV origin sequences and help to recruit cellular replication factors including DNA polymerases to viral genomes. E1 proteins also act as helicases to unwind strands of DNA ahead of replication complexes. Monomeric E1 proteins bind DNA with low affinity and form complexes with E2 proteins to facilitate their recruitment to HPV origins that are flanked by E2 binding sites [33-37]. Once recruited to origins they are assembled into stable hexameric structures, and E2 proteins are released [38,39]. In addition to their roles in replication, E2 proteins are both positive and negative regulators of viral transcription that is mediated through interactions with the bromodomain protein Brd4 [40-42]. The N-terminus of E2 contains a transactivation domain, while the C-terminus contains DNA binding sequences [43]. Truncated forms of E2 containing the C-terminus fused to a short E8 peptide generate E8 ${ }^{\wedge} \mathrm{E} 2 \mathrm{C}$ proteins that are major repressors of viral expression and replication, which prevents runaway replication [44,45].

The E4 open reading frame is expressed as fusion proteins with a short peptide from the beginning of the E1 ORF to encode E1^E4 proteins that may facilitate virion egress [13,46,47]. E5 is a small membrane protein that regulates EGFR activity [11,12]. The L1 and L2 open reading frames encode the capsid proteins and are synthesized simultaneously with productive viral replication, leading to the encapsidation of newly replicated viral genomes into progeny virions $[48,49]$.

\section{Differentiation-Dependent Viral Life Cycle}

HPV virions infect cells in the basal layer of stratified squamous epithelia that become exposed upon some form of wounding. Following entry, viral genomes migrate to the nucleus where they are established as low-copy episomes. Early transcripts encoding E6, E7, E1 and E2 are expressed resulting in the establishment of viral genomes at copy numbers of about 50 to 100 per cell [50]. These copy numbers are stably maintained in infected basal cells throughout the course of productive viral infection or until cleared by the immune response. In some cases, infections persist and progress to cancers. In cancers, HPV genomes are often found integrated in host chromosomes in a manner that retains expression of E6 and E7 but prevents that of E1 and E2 [51,52]. Replication of viral episomes in infected basal cells occurs in S-phase and is mediated by cellular polymerases and associated factors in coordination with chromosomal replication. After DNA replication is completed, viral genomes are distributed equally to each of the two daughter cells. One daughter cell remains in the basal layer and continues to actively divide while the other migrates toward the suprabasal layers and begins to differentiate $[50,53,54]$. HPV proteins only modestly alter cellular differentiation patterns and retain expression of markers such as keratin 10, filaggrin and loricrin in suprabasal layers [55]. It is not until lesions progress to cancer that the expression of these differentiation markers is lost. While normal cells exit the active cell cycle and enter G0 as they leave the basal layer, HPV-positive cells remain arrested in G1 until they reach the upper stratified layers. At this stage, HPV-positive cells re-enter S-phase, resulting in aberrant cellular replication, and transit into G2/M, 
where viral genome amplification and virion assembly occur [53]. Viral amplification in differentiated cells does not occur in S-phase but rather in G2/M because, as will be discussed below, it is dependent upon the activity of the homologous recombination repair arm of the DNA damage response that takes place in G2/M. Amplification occurs coordinately with expression of viral late transcripts that initiate from a promoter located in the E7 ORF leading to high-level expression of E2, E1, E1^E4 and E5 [50]. In addition, late transcripts encoding L1 and L2 are generated from the late promoter but require suppression of early polyadenylation signals to utilize termination elements at the end of L1 (Figure 1). This occurs through virally induced changes in the polyadenylation factor, CSTF-64 [56]. The synthesis of capsid proteins occurs coordinately with amplification resulting in the packaging of viral genomes into newly assembled virions for release from the exterior-most layers.

\section{Activation of DNA Damage Repair Pathways in HPV-Positive Cells}

HPV replication including differentiation-dependent amplification is mediated in large part by cellular enzymes whose activities have been hijacked by viral proteins. This includes polymerases and single-strand DNA binding proteins among others. Recent evidence indicates that HPV proteins activate members of the DNA damage repair pathways (DDR), and this is critical for viral replication [50]. All cells regularly acquire DNA breaks necessitating the low-level activation of DDR pathways; however, activation of these pathways is significantly enhanced in HPV-positive cells. Several DNA repair pathways with overlapping activities are responsible for the repair of both single-strand and double-strand breaks [57]. The non-homologous end joining pathway along with homologous recombination repair mediates most repairs. The primary factors regulating repair are members of the phosphatidylinositol 3-kinase-like protein kinase family (PIKK). This includes the ataxia-telangiectasia mutated (ATM), ataxia telangiectasia and RAD3-related (ATR) and the DNA-dependent protein kinase catalytic subunit (DNA-PKcs) enzymes [58]. ATM and DNA-PK are activated by double-strand breaks induced by endogenous or exogenous mechanisms such as ionizing radiation [59]. ATR is activated by single-strand DNAs that become exposed during double-strand break repair or from stalled replication forks [60,61]. Activation of both ATM and ATR is needed for HPV replication [62].

ATM proteins are activated through autophosphorylation following recruitment to sites of double-strand breaks by the MRN (Mre11-Rad50-NBS1) complex of proteins (Figure 2). Activation of ATM leads to the phosphorylation of a large number of downstream effectors and among these are the checkpoint kinase 2 (pCHK2) as well as the histone $\mathrm{H} 2 \mathrm{AX}(\gamma \mathrm{H} 2 \mathrm{AX})$ [63]. Activated CHK2 can induce a checkpoint arrest in G2/M to allow for DNA repair or induce apoptosis. Major downstream targets of pCHK2 are 53BP1, NBS1 and BRCA1 [58]. Following activation by ATM, $\gamma \mathrm{H} 2 \mathrm{AX}$ binds to regions of up to several hundred kilobases that flank the DNA break and acts to mark these lesions. ATR is activated by complex formation with ATRIP, TOPBP1 and claspin, resulting in recruitment to sites of DNA break repair or long regions of single-stranded DNAs [60,61] (Figure 2). pATR induces phosphorylation of the checkpoint kinase 1 (pCHK1), which acts similarly to CHK2 in causing cell cycle arrest in G2/M or apoptosis [64]. Major targets of pCHK1 include BRCA2, RAD51 and FANCD2 from the Fanconi anemia pathway [65]. 


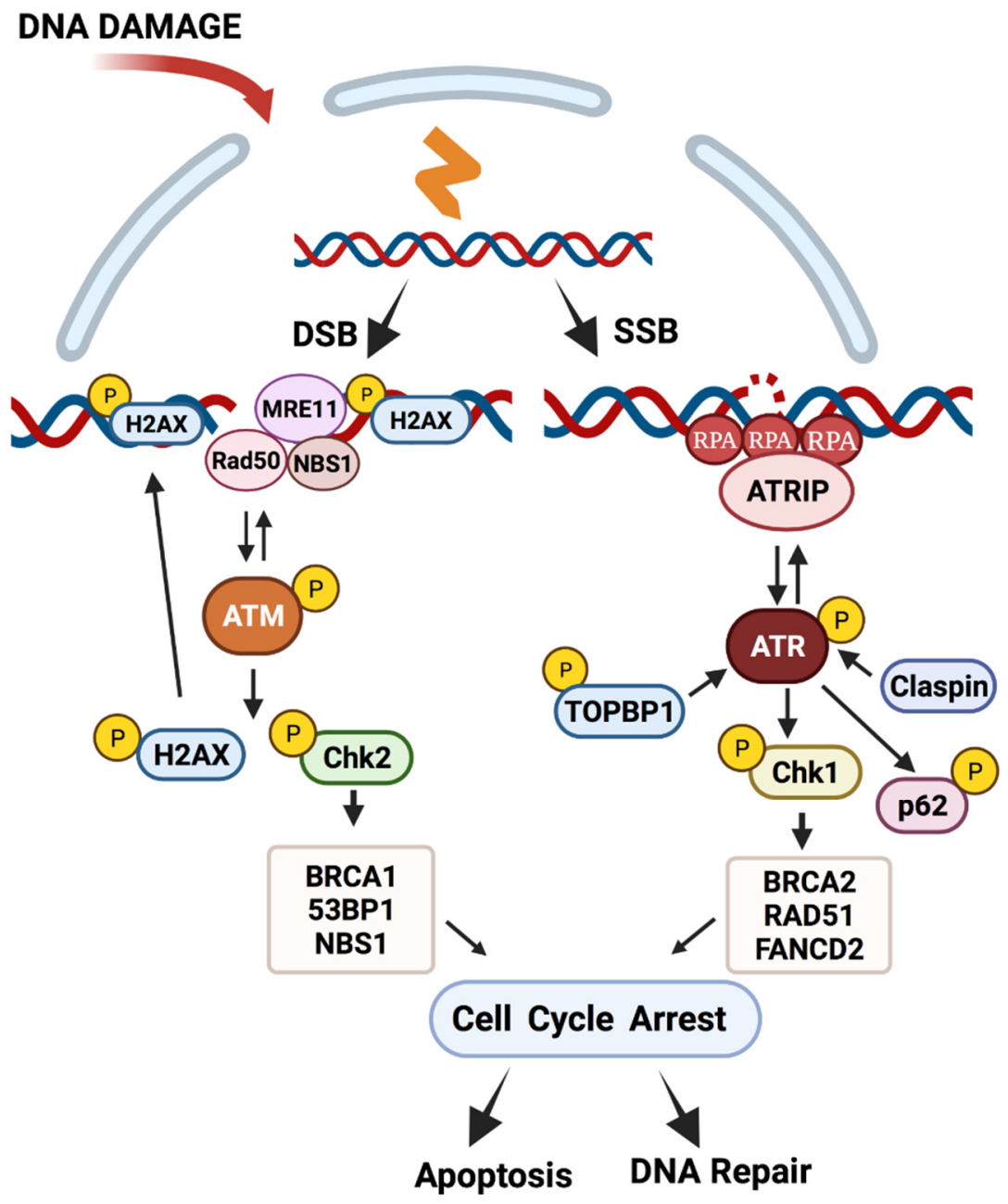

Figure 2. DNA damage repair pathways. The ATM and ATR DNA damage repair pathways are activated in response to dsDNA or ssDNA breaks/stalled replication forks, respectively. Activated ATM phosphorylates effectors such as $\mathrm{CHK} 2$, leading to the recruitment and phosphorylation of a series of DNA repair factors and cell cycle checkpoint arrest. Similarly, activated ATR phosphorylates effector protein $\mathrm{CHK} 1$, leading to activation of additional downstream factors. Both pathways mediate DNA repair through homologous recombination or otherwise eliminate the damaged cell by apoptosis or senescence. (Created with BioRender.com, 24 June 2021).

The homologous recombination arm of DNA repair takes place in G2/M as it requires the presence of a sister chromatid as a template [66]. Following recruitment of ATM to the sites of double-strand breaks by the MRN complex and activation, it phosphorylates CHK2 and the nuclease CtIP, which together with Mre11 induce end resection. This results in the generation of regions of single-stranded DNA that are quickly coated by RPA. RAD51 then replaces RPA leading to formation of filaments that mediate strand invasion of the sister chromatid and repair by DNA polymerases.

Replication fork arrest can also induce DNA breaks, which can occur through the generation of bulky DNA lesions as well as collisions of RNA polymerases with DNA polymerases, resulting in formation of trimeric RNA:DNA structures called R-loops [67]. R-loops contain an exposed region of single-strand DNA that activates the ATR pathway. ATR then activates CHK1 to induce cell cycle arrest as well as phosphorylation of a number of chromatin binding factors that mediate a restart of the stalled forks. This process is also dependent upon members of the Fanconi anemia pathway particularly FANCM $[65,68]$. Members of the Fanconi anemia pathway are also responsible for the resolution of interstrand crosslinks of DNA that also result in breaks. FANCM activation leads 
to ubiquitination of FANCD2, leading to breaks that are the repaired by the homologous recombination repair pathways. Both FANCD2 and FANCM regulate R-loop formation, which contributes to stalled replication forks and ATR activation $[65,69,70]$.

HPV-positive cells constitutively activate these pathways to levels significantly higher than normal cells $[62,71]$. This includes activation of ATM and ATR as well as their downstream effectors including pCHK1, pCHK2, $\gamma \mathrm{H} 2 \mathrm{AX}$ and pBRCA1 among others (Table 1). Activation of these DNA repair factors leads to their recruitment to distinct nuclear foci whose number and size are enhanced in HPV-positive cells. Furthermore, these foci also contain replicating HPV genomes [72]. While knockdown of ATM blocks amplification, it has minimal effects on the stable maintenance of episomes in undifferentiated cells [73]. In contrast, knockdown of ATR inhibits stable maintenance replication as well as amplification [74]. Activation of these two pathways in HPV-positive cells is not dependent on the presence of viral episomes but rather is mediated by the action of the E6 and E7 oncoproteins alone. Interestingly, overexpression of E1 from heterologous promoters also results in enhanced activation of DDR pathways, but whether this occurs when E1 is expressed at low levels from viral episomes is still unclear [54,71]. The E6 and E7 oncoproteins activate both ATM and ATR pathways (Table 1) by inducing very high levels of breaks in both cellular and viral sequences [75]. The breaks in viral episomes are rapidly repaired through the preferential recruitment of homologous recombination repair factors such as RAD51 and BRCA1 to viral genomes in differentiated cells, which leads to genome amplification [76].

Table 1. DNA damage repair factors altered by HPV oncoproteins ATM and ATR DNA damage repair factors that are activated or increased in levels through the action of E6 and E7 oncoproteins.

\begin{tabular}{cc}
\hline ATM Targets & ATR Targets \\
\hline ATM, MRE11, RAD50, NBS1, Chk2, BRCA1, & ATR, ATRIP, Chk1, TopBP1, FANCD2, FANCM, \\
RAD51, 53BP1, H2AX, RNF168, Tip60, SMC1 & BRCA1, BRCA2, RAD51, p62, H2AX \\
\hline
\end{tabular}

The cohesin protein, SMC1, functions not only in facilitating pairing of sister chromatids in G2/M but is also critical in DNA repair, allowing for the recruitment of DDR factors. SMC1 also forms complexes with the insulator protein CTCF to regulate the formation of large DNA loops called topologically associating domains or TADs that regulate both transcription and replication [77].These domains are insulated from each other, allowing actively transcribed regions to be separated from silent regions. Replication or transcription in these TADs results in significant torsional stress that is relieved by another member of the SMC1/CTCF complex, topoisomerase $2 \beta$ (TOP2 $\beta$ ) [78]. TOP2 $\beta$ induces double-strand breaks, which allows for relieving torsional stresses by forming a covalent intermediate with the cleaved DNA while strand passage occurs. Failure to quickly resolve these protein:DNA intermediates results in DNA breaks that are repaired by DDR pathways. SMC1 is activated by HPV and in complex with CTCF is recruited to viral genomes. Depletion of SMC1 or CTCF leads to the inhibition of viral amplification [79]. In addition, the levels of TOP2 $\beta$ are significantly increased in HPV-positive cells and knockdown blocks HPV replication. TOP $2 \beta$ regulates HPV replication primarily through its role in DNA break formation as over half the DNA breaks in HPV-positive cells are due to TOP $2 \beta$. Furthermore, TOP2 $\beta$-induced DNA breaks are responsible for the activation of DDR pathways in HPV-positive cells [80].

DNA topoisomerase II beta-binding protein 1 (TopBP1) is another protein involved in regulating ATR activation and HPV replication. TopBP1 binds and helps to activate ATR in addition to being a target of ATR phosphorylation. Phosphorylation of TopBP1 by ATR activates its ability to act as a transcription factor that regulates the expression of several DNA damage repair factors along with E2F1 and p73. TopBP1 levels are increased in HPV-positive cells by the immune signaling protein STAT5 through the action of E7 [74]. In addition, E2 forms complexes with TopBP1, and this is important for the maintenance of viral episomes as well as for amplification [81]. Furthermore, ATR also phosphorylates p62, a critical cargo protein in autophagy, leading to suppression of GATA4 levels and 
downregulation of expression of a number of proinflammatory host genes [82] as well as the innate immune response. Importantly, knockdown of p62 or overexpression of GATA4 blocks the maintenance of viral episomes. These data suggest a linkage between the innate immune response and activation of DNA damage repair pathways in HPV-positive cells.

\section{HPVs Alter Innate Immune Pathways}

To establish a persistent infection in keratinocytes, HPVs need to escape surveillance by the innate immune response, which is a critical host defense mechanism that has evolved as the first line of protection against pathogens. The innate immune response consists of a variety of sensors, referred to as pattern recognition receptors (PRRs), that detect the presence of foreign components such as bacterial lipopolysaccharides or viral nucleic acids such as cyclic nucleotides, ssRNA or dsRNA, cytosolic dsDNA and RNA-DNA hybrids [83]. Detection of these pathogen-associated molecular patterns (PAMPs) initiates a signaling cascade that results in the production of cytokines, such as interferons (IFNs), and the activation of hundreds of interferon-stimulated genes (ISGs), collectively creating a cellular "antiviral state". The innate immune pathways can target viral infections at different stages ranging from entry to replication and release. Since HPVs can establish persistent infections that have the potential to develop into cancer, they have evolved distinct mechanisms for long-term suppression of immune recognition pathways.

\subsection{Sensors of Innate Immunity}

HPVs interfere with several PRRs that are either membrane bound or cytosolic. Tolllike receptors (TLRs) are membrane-bound sensors that have been shown to be important in activating both innate and adaptive immunity [84]. HPV16 E6 and E7 have been identified as suppressors of TLR9 expression and function in keratinocytes through the recruitment of HDAC1 and JARID1B to the TLR9 promoter [85]. In a similar manner, the expression of TLR3 has been reported to be repressed in keratinocytes infected by hr-HPVs [86]. Interestingly, studies looking at biomarkers that can potentially predict HPV clearance have identified high levels of expression of TLRs: 3, 7, 8, 9 to be linked with viral clearance in patients $[87,88]$. Altogether, these studies suggest that TLRs have a significant role in regulating HPV infections.

HPVs have also been shown to target cytosolic DNA sensors of the innate immune pathways (Figure 3). When overexpressed, the interferon-gamma-inducible protein 16 (IFI16) DNA sensor can inhibit HPV18 replication and transcription [89]. Similarly, depletion of IFI16 in keratinocytes results in higher viral loads [90]. The absent in melanoma 2 or AIM2 is a PRR that is part of the inflammasome and is activated by HPV16 leading to enhanced production of IL-1 $\beta$ and IL-18 [91]. Interestingly, both IFI16 and AIM2 have been shown to be upregulated in HPV-positive cervical biopsies as well as head and neck carcinomas [91,92]. The recently identified sensor cyclic GMP-AMP synthetase (cGAS) [93-95] is another target of HPVs. HPV has been reported to silence cGAS signaling during viral entry through its effects on L2-dependent vesicular trafficking [96]. It remains controversial what effect persistent HPV infections have on the cGAS pathway as some reports suggest repression, while others increased expression. 


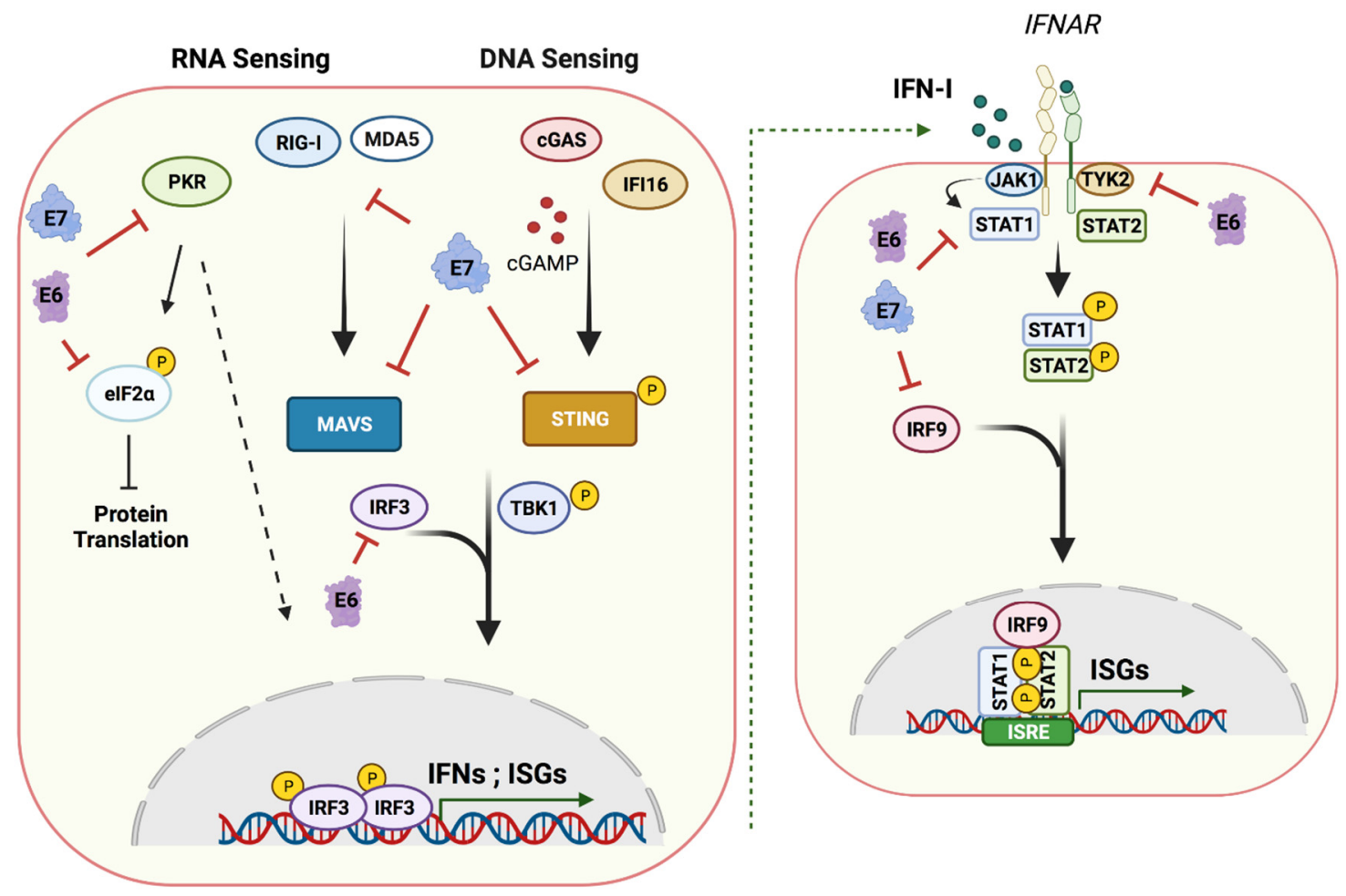

Figure 3. Host nucleic acid sensing pathways and targets of E6 and E7. A cartoon showing cytoplasmic nucleic acid sensors and their signaling cascades inducing type I IFN production and ISG expression that are targeted by E6 and E7 (left panel). A cartoon showing the effects of secreted IFNs on neighboring cells through activation of the JAK-STAT pathway leading to an antiviral state (right). HPV oncoproteins E6 and E7 manipulate these pathways at different stages, damping the innate immune response and establishing a persistent infection. (Created with BioRender.com, 24 June 2021).

RNA sensors such as dsRNA protein kinase (PKR), retinoic-acid-inducible gene I (RIG-I) and MDA5 have also been identified as targets of HPVs. The levels of RIG-I and MDA5 transcripts in keratinocytes infected with hr-HPVs were found to be significantly reduced [86]. RIG-I signaling was also disrupted by E6 binding to TRIM25 and USP15, two upstream regulators of RIG-I [97]. In addition, E7 has been reported to induce epigenetic silencing of RIG-I and cGAS [98]. In a similar manner, cells containing either HPV16 or 31 genomes exhibited a reduction of PKR transcripts along with reduced levels of active, phosphorylated levels of PKR proteins that were mediated by E6 and E7 through post-transcriptional mechanisms [99]. PKR controls protein translation through eIF2 $\alpha$ phosphorylation and is a critical regulator of antiviral immunity as well as maintenance of cell homeostasis. E6 binding to the GADD34/PP1 phosphatase complex directly inhibits phosphorylation of eIF2 $\alpha$ [100], while HPV16 E6 relocates it to cytoplasmic clusters that co-localize with P-bodies [99].

\subsection{Adaptors and Signaling Proteins}

Adaptor proteins link the signaling from cytoplasmic sensors to the nucleus to initiate an innate immune response against pathogens (Figure 3). The stimulator of interferon genes (STING) serves as a signaling adaptor for IFI16 and cGAS. Upon binding of cGAS to dsDNA, cyclic GMP-AMP (cGAMP), a second messenger, gets synthesized [93,95,101,102]. cGAMP is recognized by and binds STING, leading to its activation [94,103]. STING is initially localized to the ER, and following activation by cGAMP, it migrates to the Golgi where it binds TBK1, leading to its autophosphorylation along with phosphorylation of the interferon regulatory factor IRF3. Activated IRF3 finally translocates to the nucleus to induce IFN and ISGs expression [104]. STING is also a downstream mediator of IFI16 signaling [89]. Given the importance of STING in signaling to the nucleus, it is targeted by many viruses including HPV. The E2 protein has been reported to suppress STING 
expression along with that of many other innate immune proteins [105]. The E7 protein also alters STING expression through epigenetic silencing [98]. Furthermore, HPV18 E7 has been reported to bind STING through its LXCXE motif, resulting in inhibition of its function [106]. Recent work in oropharyngeal carcinomas showed that depletion of E7 can restore cGAS-STING signaling [107]. Additionally, E6 of HPV16 binds directly to IRF3, hence possibly interfering with its transcription activation in the nucleus [108]. It appears that there are many ways HPVs interact with the cGAS-STING pathway, and the details of these mechanisms remain to be fully determined.

\subsection{IFN Signaling and ISGS}

The endpoint of these innate signaling pathways is ISGs expression and IFN production. IFNs are classified into three types according to their sequence homology and to the receptors they signal through. IFN production and ISG expression provide two major functions: the first is to clear the viral infection and/or eliminate the infected cell; the second is to signal neighboring cells through secreted IFNs by initiating an antiviral program. Upon binding of IFNs to receptors on the surface of neighboring cells, Janus kinases (JAKs), which are bound to the cytoplasmic tails of receptors, become activated and phosphorylate a series of inactive transcriptional activators called STATs that are found in the cytoplasm. Phosphorylated STATs (predominantly STAT1 and STAT2) translocate to the nucleus to bind ISG promoter regions to activate transcription (Figure 3). Given the critical role of JAK-STAT signaling in controlling the interferon response to viral infections, it is targeted by HPVs in several ways (Figure 3). The transcription of STAT1 along with that of many other ISGs is silenced by both E6 and E7 oncoproteins [109,110]. If STAT1 levels are restored in HPV-positive cells using heterologous expression vectors, episomal templates are significantly reduced, and amplification is blocked [111]. Examination of STAT1 levels in cervical squamous carcinomas biopsies indicated a direct correlation between viral load and stage of disease [112]. Together, these studies confirm the overall importance of downmodulation of STAT1 by HPV proteins.

In contrast to STAT1, HPVs appear to activate STAT5 and STAT3, which have been implicated in the development of a number of solid cancers (reviewed in detail in [113]). HPV E7 induces STAT5 phosphorylation, and this is important for high-level activation of ATM and ATR DNA repair pathways [114]. Transcription factor KLF13 was identified as responsible for increased STAT5 levels during HPV infection. Depletion of KLF13 correlated with decreased STAT5 expression along with impaired DDR activation and genome amplification [115]. Similarly, STAT3 phosphorylation is activated by HPV proteins. Activation of STAT3 is linked to enhanced cell proliferation along with inhibition of differentiation leading to immortalization [116]. Furthermore, cervical cancer tissues positive for HPV display high levels of activated STAT3 when compared to normal tissues [117]. In addition, E6 induces activation of the transcription factor $\mathrm{NF \kappa B}$, resulting in IL-6 production leading to STAT3 phosphorylation and nuclear localization [118,119]. Altogether, these studies emphasize the ability of HPVs to target different members of the STAT family leading to immune evasion and enhanced proliferation.

HPVs suppress the expression of IFN- $\alpha$ and IFN- $\beta$ through interference with STATs and binding kinase Tyk2 [120]. Keratinocytes express a specific type of IFN known as IFN $\mathrm{k}$, with $\mathrm{k}$ standing for keratinocyte, that is constitutively expressed at low levels and is upregulated following viral infection [121]. HPV E6 and E7 suppress IFNא expression through epigenetic silencing as well as through p62-mediated suppression of GATA4 expression. Restoring IFNK expression in HPV-positive keratinocytes results in increased levels of IFN-regulatory factors and p53 [122]. Furthermore, E2 and E5 also act to suppress IFNK and STAT1 levels $[105,123,124]$. Importantly, treatment of HPV-positive cell lines with IFNK inhibited viral replication and cell growth, further demonstrating the importance of suppressing this interferon upon viral infection [125]. Hr-HPVs also target the interferonrelated developmental regulator 1 by increasing its expression in an EGFR-dependent manner and preventing NFKB activation, leading to limited cytokine production [126]. 
The manipulation of IFN signaling by HPVs subsequently leads to the suppression of ISG expression. Analysis of patient biopsies and cell lines has identified Mx1, IFI56, OAS, ISG15, IFIT1, IFITM, RIG-I and MDA5 as prominent ISGs whose expression is suppressed by HPV proteins $[82,86,109,125,127,128]$. Most of the studies on IFNs and ISGs have been performed on cells with established HPV infections, and the events that occur during viral entry are not yet fully understood.

\section{DAMPs Connect DNA Damage and Innate Immunity during HPV Infection}

The innate immune response is activated in response not only to foreign nucleic acids but also to "misplaced" self-DNAs that arise during periods of DNA damage. These damage-associated molecular patterns or DAMPs are markers of cellular malfunction and are detected by innate immune sensors that can lead to programed cell death. Genotoxic stress induces genomic instability that causes DNA breaks. These broken DNA fragments can leak into the cytosol, where they are recognized by the PPRs. Sensors such as cGAS, IFI16 and RIG-I but also STING have been linked to genomic instability [129-133]. This crosstalk between genomic instability, DNA repair and innate immunity is critical in maintaining cell homeostasis, and currently there is an increased interest in the use of immune nucleic acid sensing pathways in targeting cancer [134].

As described in detail previously, HPV oncoproteins induce DNA breaks in infected cells to activate DDR mechanisms, which are important for viral amplification. A linkage between the DNA damage response and innate immunity in HPV-positive cells is suggested by studies linking ATR activation with phosphorylation of the autophagy protein p62, which in turn acts to suppress the transcription factor GATA4. This results in the suppression of cytokines such as IL-5 and CXCL2 and IFNK expression [82]. Ongoing studies indicate cGAS may act to inhibit DNA repair in HPV-positive cells in a STING-independent manner. In response to DNA damage, cGAS translocates to the nucleus, where it associates with chromatin to downregulate homologous recombination repair [135]. Additional reports suggest cGAS localizes to micronuclei upon DNA damage [136]. The genomic instability caused by HPV could be a successful target for efficient therapeutics through innate immune activation, hence preventing malignant progression. For instance, ATR inhibitors have been used to treat HPV-positive oropharyngeal cancers, but the morbidity of these treatments remains high. Inclusion of activators of the innate immune response may make treatments more effective and reduce the side effects. In conclusion, crosstalk between DNA damage repair pathways and innate immune signaling may affect critical cellular processes such as autophagy, senescence and apoptosis during HPV infections.

\section{Conclusions}

In this review article, we have described the current knowledge of two major pathways used by hr-HPVs to establish long-term persistent infections. HPVs activate host DNA damage repair pathways to allow for genome amplification upon differentiation as well as to manipulate the innate immune responses to avoid clearance. Furthermore, it appears that these two pathways are interlinked, and HPVs need to target both for a successful infection. These studies describe biomarkers that may facilitate prognosis as well as novel ways to efficiently target and treat HPV-positive anogenital and oropharyngeal cancers.

Author Contributions: Conceptualization: E.G. and L.L.; writing original draft: E.G. and L.L.; writing-review and editing: E.G. and L.L. Funding: L.L. Both authors have read and agreed to the published version of the manuscript.

Funding: This research received no external funding.

Institutional Review Board Statement: Not Applicable.

Informed Consent Statement: Not Applicable.

Data Availability Statement: Not Applicable.

Conflicts of Interest: Authors declare no conflict of interest. 


\section{References}

1. Zur Hausen, H. Papillomaviruses in the causation of human cancers-A brief historical account. Virology 2009, 384, 260-265. [CrossRef]

2. Walboomers, J.M.; Jacobs, M.V.; Manos, M.M.; Bosch, F.X.; Kummer, J.A.; Shah, K.V.; Snijders, P.J.; Peto, J.; Meijer, C.J.; Munoz, N. Human papillomavirus is a necessary cause of invasive cervical cancer worldwide. J. Pathol. 1999, 189, 12-19. [CrossRef]

3. Castellsagué, X.; Alemany, L.; Quer, M.; Halec, G.; Quirós, B.; Tous, S.; Clavero, O.; Alòs, L.; Biegner, T.; Szafarowski, T.; et al. HPV Involvement in Head and Neck Cancers: Comprehensive Assessment of Biomarkers in 3680 Patients. J. Natl. Cancer Inst. 2016, 108, djv403. [CrossRef] [PubMed]

4. Lorincz, A.T.; Reid, R.; Jenson, B.A.; Greenberg, M.D.; Lancaster, W.; Kurman, R.J. Human Papillomavirus Infection of the Cervix: Relative Risk Associations of 15 Common Anogenital Types. Obstet. Gynecol. 1992, 79, 328-337. [CrossRef]

5. Stubenrauch, F.; Laimins, L.A. Human papillomavirus life cycle: Active and latent phases. Semin. Cancer Biol. 1999, 9, 379-386. [CrossRef]

6. Doorbar, J.; Quint, W.; Banks, L.; Bravo, I.G.; Stoler, M.; Broker, T.R.; Stanley, M.A. The Biology and Life-Cycle of Human Papillomaviruses. Vaccine 2012, 30 (Suppl. 5), F55-F70. [CrossRef] [PubMed]

7. Rohlfs, M.; Winkenbach, S.; Meyer, S.; Rupp, T.; Dürst, M. Viral transcription in human keratinocyte cell lines immortalized by human papillomavirus type-16. Virology 1991, 183, 331-342. [CrossRef]

8. Del Vecchio, A.M.; Romanczuk, H.; Howley, P.M.; Baker, C.C. Transient replication of human papillomavirus DNAs. J. Virol. 1992, 66, 5949-5958. [CrossRef] [PubMed]

9. Ozbun, M.A. Human Papillomavirus Type 31b Infection of Human Keratinocytes and the Onset of Early Transcription. J. Virol. 2002, 76, 11291-11300. [CrossRef]

10. Yang, L.; Li, R.; Mohr, I.J.; Clark, R.; Botchan, M.R. Activation of BPV-1 replication in vitro by the transcription factor E2. Nature 1991, 353, 628-632. [CrossRef] [PubMed]

11. Fehrmann, F.; Klumpp, D.J.; Laimins, L.A. Human Papillomavirus Type 31 E5 Protein Supports Cell Cycle Progression and Activates Late Viral Functions upon Epithelial Differentiation. J. Virol. 2003, 77, 2819-2831. [CrossRef] [PubMed]

12. Genther, S.M.; Sterling, S.; Duensing, S.; Munger, K.; Sattler, C.; Lambert, P.F. Quantitative Role of the Human Papillomavirus Type 16 E5 Gene during the Productive Stage of the Viral Life Cycle. J. Virol. 2003, 77, 2832-2842. [CrossRef] [PubMed]

13. Wilson, R.; Ryan, G.B.; Knight, G.L.; Laimins, L.A.; Roberts, S. The full-length E1^E4 protein of human papillomavirus type 18 modulates differentiation-dependent viral DNA amplification and late gene expression. Virology 2007, 362, 453-460. [CrossRef]

14. Scheffner, M.; Huibregtse, J.M.; Vierstra, R.D.; Howley, P.M. The HPV-16 E6 and E6-AP complex functions as a ubiquitin-protein ligase in the ubiquitination of p53. Cell 1993, 75, 495-505. [CrossRef]

15. Martinez-Zapien, D.; Ruiz, F.X.; Poirson, J.; Mitschler, A.; Ramirez, J.; Forster, A.; Cousido-Siah, A.; Masson, M.; Pol, S.V.; Podjarny, A.; et al. Structure of the E6/E6AP/p53 complex required for HPV-mediated degradation of p53. Nature 2016, 529, 541-545. [CrossRef] [PubMed]

16. Gewin, L.; Galloway, D.A. E Box-Dependent Activation of Telomerase by Human Papillomavirus Type 16 E6 Does Not Require Induction of c-myc. J. Virol. 2001, 75, 7198-7201. [CrossRef]

17. Oh, S.T.; Kyo, S.; Laimins, L.A. Telomerase Activation by Human Papillomavirus Type 16 E6 Protein: Induction of Human Telomerase Reverse Transcriptase Expression through Myc and GC-Rich Sp1 Binding Sites. J. Virol. 2001, 75, 5559-5566. [CrossRef]

18. Veldman, T.; Horikawa, I.; Barrett, J.C.; Schlegel, R. Transcriptional Activation of the Telomerase hTERT Gene by Human Papillomavirus Type 16 E6 Oncoprotein. J. Virol. 2001, 75, 4467-4472. [CrossRef]

19. Katzenellenbogen, R.A.; Vliet-Gregg, P.; Xu, M.; Galloway, D.A. NFX1-123 Increases hTERT Expression and Telomerase Activity Posttranscriptionally in Human Papillomavirus Type 16 E6 Keratinocytes. J. Virol. 2009, 83, 6446-6456. [CrossRef]

20. Lee, C.; Laimins, L.A. Role of the PDZ Domain-Binding Motif of the Oncoprotein E6 in the Pathogenesis of Human Papillomavirus Type 31. J. Virol. 2004, 78, 12366-12377. [CrossRef]

21. Massimi, P.; Gammoh, N.; Thomas, M.; Banks, L. HPV E6 specifically targets different cellular pools of its PDZ domain-containing tumour suppressor substrates for proteasome-mediated degradation. Oncogene 2004, 23, 8033-8039. [CrossRef]

22. Thomas, M.; Massimi, P.; Navarro, C.; Borg, J.-P.; Banks, L. The hScrib/Dlg apico-basal control complex is differentially targeted by HPV-16 and HPV-18 E6 proteins. Oncogene 2005, 24, 6222-6230. [CrossRef]

23. Tan, M.J.A.; White, E.A.; Sowa, M.E.; Harper, J.W.; Aster, J.C.; Howley, P.M. Cutaneous $\beta$-human papillomavirus E6 proteins bind Mastermind-like coactivators and repress Notch signaling. Proc. Natl. Acad. Sci. USA 2012, 109, E1473-E1480. [CrossRef] [PubMed]

24. Brimer, N.; Lyons, C.; Wallberg, A.E.; Pol, S.B.V. Cutaneous papillomavirus E6 oncoproteins associate with MAML1 to repress transactivation and NOTCH signaling. Oncogene 2012, 31, 4639-4646. [CrossRef] [PubMed]

25. Zhang, B.; Chen, W.; Roman, A. The E7 proteins of low- and high-risk human papillomaviruses share the ability to target the pRB family member p130 for degradation. Proc. Natl. Acad. Sci. USA 2006, 103, 437-442. [CrossRef] [PubMed]

26. Huang, P.S.; Patrick, D.R.; Edwards, G.; Goodhart, P.J.; Huber, H.E.; Miles, L.; Garsky, V.M.; Oliff, A.; Heimbrook, D.C. Protein domains governing interactions between E2F, the retinoblastoma gene product, and human papillomavirus type 16 E7 protein. Mol. Cell. Biol. 1993, 13, 953-960. [CrossRef] [PubMed]

27. Boyer, S.N.; Wazer, D.E.; Band, V. E7 protein of human papilloma virus-16 induces degradation of retinoblastoma protein through the ubiquitin-proteasome pathway. Cancer Res. 1996, 56, 4620-4624. [PubMed] 
28. Dyson, N.; Howley, P.M.; Munger, K.; Harlow, E. The human papilloma virus-16 E7 oncoprotein is able to bind to the retinoblastoma gene product. Science 1989, 243, 934-937. [CrossRef]

29. Heck, D.V.; Yee, C.L.; Howley, P.M.; Munger, K. Efficiency of binding the retinoblastoma protein correlates with the transforming capacity of the E7 oncoproteins of the human papillomaviruses. Proc. Natl. Acad. Sci. USA 1992, 89, 4442-4446. [CrossRef]

30. Huh, K.-W.; DeMasi, J.; Ogawa, H.; Nakatani, Y.; Howley, P.M.; Munger, K. Association of the human papillomavirus type 16 E7 oncoprotein with the 600-kDa retinoblastoma protein-associated factor, p600. Proc. Natl. Acad. Sci. USA 2005, 102, 11492-11497. [CrossRef]

31. Bodily, J.M.; Mehta, K.P.M.; Laimins, L.A. Human Papillomavirus E7 Enhances Hypoxia-Inducible Factor 1-Mediated Transcription by Inhibiting Binding of Histone Deacetylases. Cancer Res. 2011, 71, 1187-1195. [CrossRef]

32. Zhang, B.; Laribee, R.N.; Klemsz, M.J.; Roman, A. Human papillomavirus type 16 E7 protein increases acetylation of histone H3 in human foreskin keratinocytes. Virology 2004, 329, 189-198. [CrossRef] [PubMed]

33. Mohr, I.J.; Clark, R.; Sun, S.; Androphy, E.J.; MacPherson, P.; Botchan, M.R. Targeting the E1 replication protein to the papillomavirus origin of replication by complex formation with the E2 transactivator. Science 1990, 250, 1694-1699. [CrossRef]

34. Sedman, J.; Stenlund, A. Co-operative interaction between the initiator E1 and the transcriptional activator E2 is required for replicator specific DNA replication of bovine papillomavirus in vivo and in vitro. EMBO J. 1995, 14, 6218-6228. [CrossRef] [PubMed]

35. Frattini, M.G.; Laimins, L.A. The Role of the E1 and E2 Proteins in the Replication of Human Papillomavirus Type 31b. Virology 1994, 204, 799-804. [CrossRef]

36. Frattini, M.G.; Laimins, L.A. Binding of the human papillomavirus E1 origin-recognition protein is regulated through complex formation with the E2 enhancer-binding protein. Proc. Natl. Acad. Sci. USA 1994, 91, 12398-12402. [CrossRef]

37. Ustav, M.; Ustav, E.; Szymanski, P.; Stenlund, A. Identification of the origin of replication of bovine papillomavirus and characterization of the viral origin recognition factor E1. EMBO J. 1991, 10, 4321-4329. [CrossRef]

38. Sedman, J.; Stenlund, A. The Papillomavirus E1 Protein Forms a DNA-Dependent Hexameric Complex with ATPase and DNA Helicase Activities. J. Virol. 1998, 72, 6893-6897. [CrossRef]

39. Sanders, C.M.; Stenlund, A. Recruitment and loading of the E1 initiator protein: An ATP-dependent process catalysed by a transcription factor. EMBO J. 1998, 17, 7044-7055. [CrossRef] [PubMed]

40. Wu, S.-Y.; Nin, D.S.; Lee, A.-Y.; Simanski, S.; Kodadek, T.; Chiang, C.-M. BRD4 Phosphorylation Regulates HPV E2-Mediated Viral Transcription, Origin Replication, and Cellular MMP-9 Expression. Cell Rep. 2016, 16, 1733-1748. [CrossRef] [PubMed]

41. Jang, M.K.; Kwon, D.; McBride, A.A. Papillomavirus E2 Proteins and the Host Brd4 Protein Associate with Transcriptionally Active Cellular Chromatin. J. Virol. 2009, 83, 2592-2600. [CrossRef]

42. Chiang, C.M.; Ustav, M.; Stenlund, A.; Ho, T.F.; Broker, T.R.; Chow, L.T. Viral E1 and E2 proteins support replication of homologous and heterologous papillomaviral origins. Proc. Natl. Acad. Sci. USA 1992, 89, 5799-5803. [CrossRef] [PubMed]

43. McBride, A.A. The Papillomavirus E2 proteins. Virology 2013, 445, 57-79. [CrossRef] [PubMed]

44. Straub, E.; Dreer, M.; Fertey, J.; Iftner, T.; Stubenrauch, F. The Viral E8^E2C Repressor Limits Productive Replication of Human Papillomavirus 16. J. Virol. 2014, 88, 937-947. [CrossRef]

45. Lace, M.J.; Anson, J.R.; Thomas, G.S.; Turek, L.P.; Haugen, T.H. The E8 ${ }^{\wedge}$ E2 Gene Product of Human Papillomavirus Type 16 Represses Early Transcription and Replication but Is Dispensable for Viral Plasmid Persistence in Keratinocytes. J. Virol. 2008, 82, 10841-10853. [CrossRef] [PubMed]

46. Wilson, R.; Fehrmann, F.; Laimins, L.A. Role of the E1 ${ }^{\wedge}$ E4 Protein in the Differentiation-Dependent Life Cycle of Human Papillomavirus Type 31. J. Virol. 2005, 79, 6732-6740. [CrossRef]

47. Doorbar, J.; Ely, S.; Sterling, J.; McLean, C.; Crawford, L. Specific interaction between HPV-16 E1-E4 and cytokeratins results in collapse of the epithelial cell intermediate filament network. Nature 1991, 352, 824-827. [CrossRef] [PubMed]

48. Okun, M.M.; Day, P.M.; Greenstone, H.L.; Booy, F.P.; Lowy, D.R.; Schiller, J.T.; Roden, R.B.S. L1 Interaction Domains of Papillomavirus L2 Necessary for Viral Genome Encapsidation. J. Virol. 2001, 75, 4332-4342. [CrossRef]

49. Zhou, J.; Sun, X.Y.; Stenzel, D.J.; Frazer, I.H. Expression of vaccinia recombinant HPV 16 L1 and L2 ORF proteins in epithelial cells is sufficient for assembly of HPV virion-like particles. Virology 1991, 185, 251-257. [CrossRef]

50. Moody, C.A.; Laimins, L.A. Human papillomavirus oncoproteins: Pathways to transformation. Nat. Rev. Cancer 2010, 10, 550-560. [CrossRef]

51. Tomaić, V. Functional Roles of E6 and E7 Oncoproteins in HPV-Induced Malignancies at Diverse Anatomical Sites. Cancers 2016, 8, 95. [CrossRef]

52. McBride, A.A.; Warburton, A. The role of integration in oncogenic progression of HPV-associated cancers. PLoS Pathog. 2017, 13, e1006211. [CrossRef]

53. Cheng, S.; Schmidt-Grimminger, D.C.; Murant, T.; Broker, T.R.; Chow, L.T. Differentiation-dependent up-regulation of the human papillomavirus E7 gene reactivates cellular DNA replication in suprabasal differentiated keratinocytes. Genes Dev. 1995, 9, 2335-2349. [CrossRef] [PubMed]

54. Sakakibara, N.; Chen, D.; McBride, A.A. Papillomaviruses Use Recombination-Dependent Replication to Vegetatively Amplify Their Genomes in Differentiated Cells. PLoS Pathog. 2013, 9, e1003321. [CrossRef] [PubMed] 
55. Ruesch, M.N.; Stubenrauch, F.; Laimins, L.A. Activation of Papillomavirus Late Gene Transcription and Genome Amplification upon Differentiation in Semisolid Medium Is Coincident with Expression of Involucrin and Transglutaminase but Not Keratin-10. J. Virol. 1998, 72, 5016-5024. [CrossRef]

56. Terhune, S.S.; Milcarek, C.; Laimins, L.A. Regulation of Human Papillomavirus Type 31 Polyadenylation during the Differentiation-Dependent Life Cycle. J. Virol. 1999, 73, 7185-7192. [CrossRef] [PubMed]

57. Ciccia, A.; Elledge, S.J. The DNA Damage Response: Making It Safe to Play with Knives. Mol. Cell 2010, 40, 179-204. [CrossRef]

58. Harper, J.W.; Elledge, S.J. The DNA Damage Response: Ten Years After. Mol. Cell 2007, 28, 739-745. [CrossRef] [PubMed]

59. Shiloh, Y. ATM and related protein kinases: Safeguarding genome integrity. Nat. Rev. Cancer 2003, 3, 155-168. [CrossRef] [PubMed]

60. Williams, R.M.; Zhang, X. Roles of ATM and ATR in DNA double strand breaks and replication stress. Prog. Biophys. Mol. Biol. 2021, 161, 27-38. [CrossRef]

61. Buisson, R.; Niraj, J.; Rodrigue, A.; Ho, C.K.; Kreuzer, J.; Foo, T.K.; Hardy, E.J.-L.; Dellaire, G.; Haas, W.; Xia, B.; et al. Coupling of Homologous Recombination and the Checkpoint by ATR. Mol. Cell 2017, 65, 336-346. [CrossRef] [PubMed]

62. Moody, C.A.; Laimins, L.A. Human Papillomaviruses Activate the ATM DNA Damage Pathway for Viral Genome Amplification upon Differentiation. PLoS Pathog. 2009, 5, e1000605. [CrossRef]

63. Rogakou, E.P.; Pilch, D.R.; Orr, A.H.; Ivanova, V.S.; Bonner, W.M. DNA Double-stranded Breaks Induce Histone H2AX Phosphorylation on Serine 139. J. Biol. Chem. 1998, 273, 5858-5868. [CrossRef] [PubMed]

64. Cimprich, K.A.; Cortez, D. ATR: An essential regulator of genome integrity. Nat. Rev. Mol. Cell Biol. 2008, 9, 616-627. [CrossRef] [PubMed]

65. Liang, Z.; Liang, F.; Teng, Y.; Chen, X.; Liu, J.; Longerich, S.; Rao, T.; Green, A.M.; Collins, N.B.; Xiong, Y.; et al. Binding of FANCI-FANCD2 Complex to RNA and R-Loops Stimulates Robust FANCD2 Monoubiquitination. Cell Rep. 2019, 26, 564-572.e5. [CrossRef]

66. Wright, W.D.; Shah, S.S.; Heyer, W.-D. Homologous recombination and the repair of DNA double-strand breaks. J. Biol. Chem. 2018, 293, 10524-10535. [CrossRef]

67. Niehrs, C.; Luke, B. Regulatory R-loops as facilitators of gene expression and genome stability. Nat. Rev. Mol. Cell Biol. 2020, 21, 167-178. [CrossRef]

68. Singh, T.R.; Ali, A.M.; Paramasivam, M.; Pradhan, A.; Wahengbam, K.; Seidman, M.M.; Meetei, A.R. ATR-Dependent Phosphorylation of FANCM at Serine 1045 Is Essential for FANCM Functions. Cancer Res. 2013, 73, 4300-4310. [CrossRef] [PubMed]

69. Okamoto, Y.; Abe, M.; Itaya, A.; Tomida, J.; Ishiai, M.; Takaori-Kondo, A.; Taoka, M.; Isobe, T.; Takata, M. FANCD 2 protects genome stability by recruiting RNA processing enzymes to resolve R-loops during mild replication stress. FEBS J. 2018, 286, 139-150. [CrossRef]

70. Silva, B.; Pentz, R.; Figueira, A.M.; Arora, R.; Lee, Y.W.; Hodson, C.; Wischnewski, H.; Deans, A.J.; Azzalin, C.M. FANCM limits ALT activity by restricting telomeric replication stress induced by deregulated BLM and R-loops. Nat. Commun. 2019, 10, 2253. [CrossRef]

71. Kadaja, M.; Isok-Paas, H.; Laos, T.; Ustav, E.; Ustav, M. Mechanism of Genomic Instability in Cells Infected with the High-Risk Human Papillomaviruses. PLoS Pathog. 2009, 5, e1000397. [CrossRef] [PubMed]

72. Anacker, D.C.; Gautam, D.; Gillespie, K.A.; Chappell, W.H.; Moody, C.A. Productive Replication of Human Papillomavirus 31 Requires DNA Repair Factor Nbs1. J. Virol. 2014, 88, 8528-8544. [CrossRef] [PubMed]

73. Edwards, T.G.; Helmus, M.J.; Koeller, K.; Bashkin, J.K.; Fisher, C. Human Papillomavirus Episome Stability Is Reduced by Aphidicolin and Controlled by DNA Damage Response Pathways. J. Virol. 2013, 87, 3979-3989. [CrossRef] [PubMed]

74. Hong, S.; Cheng, S.; Iovane, A.; Laimins, L.A. STAT-5 Regulates Transcription of the Topoisomerase II $\beta$-Binding Protein 1 (TopBP1) Gene to Activate the ATR Pathway and Promote Human Papillomavirus Replication. mBio 2015, 6, e02006-15. [CrossRef] [PubMed]

75. Duensing, S.; Münger, K. The human papillomavirus type 16 E6 and E7 oncoproteins independently induce numerical and structural chromosome instability. Cancer Res. 2002, 62, 7075-7082. [PubMed]

76. Mehta, K.; Laimins, L. Human Papillomaviruses Preferentially Recruit DNA Repair Factors to Viral Genomes for Rapid Repair and Amplification. mBio 2018, 9. [CrossRef]

77. Gosalia, N.; Neems, D.; Kerschner, J.L.; Kosak, S.T.; Harris, A. Architectural proteins CTCF and cohesin have distinct roles in modulating the higher order structure and expression of the CFTR locus. Nucleic Acids Res. 2014, 42, 9612-9622. [CrossRef]

78. Uusküla-Reimand, L.; Hou, H.; Samavarchi-Tehrani, P.; Rudan, M.V.; Liang, M.; Medina-Rivera, A.; Mohammed, H.; Schmidt, D.; Schwalie, P.; Young, E.J.; et al. Topoisomerase II beta interacts with cohesin and CTCF at topological domain borders. Genome Biol. 2016, 17, 182. [CrossRef]

79. Mehta, K.; Gunasekharan, V.; Satsuka, A.; Laimins, L.A. Human Papillomaviruses Activate and Recruit SMC1 Cohesin Proteins for the Differentiation-Dependent Life Cycle through Association with CTCF Insulators. PLoS Pathog. 2015, 11, e1004763. [CrossRef]

80. Kaminski, P.; Hong, S.; Kono, T.; Hoover, P.; Laimins, L. Topoisomerase 2 $\beta$ Induces DNA Breaks to Regulate Human Papillomavirus Replication. mBio 2021, 12. [CrossRef] 
81. Donaldson, M.M.; Mackintosh, L.J.; Bodily, J.M.; Dornan, E.S.; Laimins, L.A.; Morgan, I.M. An Interaction between Human Papillomavirus 16 E2 and TopBP1 Is Required for Optimum Viral DNA Replication and Episomal Genome Establishment. J. Virol. 2012, 86, 12806-12815. [CrossRef] [PubMed]

82. Hong, S.; Li, Y.; Kaminski, P.J.; Andrade, J.; Laimins, L.A. Pathogenesis of Human Papillomaviruses Requires the ATR/p62 Autophagy-Related Pathway. mBio 2020, 11. [CrossRef] [PubMed]

83. Tan, X.; Sun, L.; Chen, J.; Chen, Z.J. Detection of Microbial Infections Through Innate Immune Sensing of Nucleic Acids. Annu. Rev. Microbiol. 2018, 72, 447-478. [CrossRef]

84. Urban-Wojciuk, Z.; Khan, M.M.; Oyler, B.L.; Fåhraeus, R.; Marek-Trzonkowska, N.; Nita-Lazar, A.; Hupp, T.R.; Goodlett, D.R. The Role of TLRs in Anti-cancer Immunity and Tumor Rejection. Front. Immunol. 2019, 10, 2388. [CrossRef]

85. Hasan, U.A.; Zannetti, C.; Parroche, P.; Goutagny, N.; Malfroy, M.; Roblot, G.; Carreira, C.; Hussain, I.; Müller, M.; TaylorPapadimitriou, J.; et al. The Human papillomavirus type 16 E7 oncoprotein induces a transcriptional repressor complex on the Toll-like receptor 9 promoter. J. Exp. Med. 2013, 210, 1369-1387. [CrossRef]

86. Reiser, J.; Hurst, J.; Voges, M.; Krauss, P.; Münch, P.; Iftner, T.; Stubenrauch, F. High-Risk Human Papillomaviruses Repress Constitutive Kappa Interferon Transcription via E6 To Prevent Pathogen Recognition Receptor and Antiviral-Gene Expression. J. Virol. 2011, 85, 11372-11380. [CrossRef] [PubMed]

87. Daud, I.I.; Scott, M.E.; Ma, Y.; Shiboski, S.; Farhat, S.; Moscicki, A.-B. Association between toll-like receptor expression and human papillomavirus type 16 persistence. Int. J. Cancer 2011, 128, 879-886. [CrossRef]

88. Scott, M.E.; Ma, Y.; Farhat, S.; Moscicki, A.-B. Expression of nucleic acid-sensing Toll-like receptors predicts HPV16 clearance associated with an E6-directed cell-mediated response. Int. J. Cancer 2015, 136, 2402-2408. [CrossRef]

89. Unterholzner, L.; Keating, S.E.; Baran, M.; Horan, K.A.; Jensen, S.B.; Sharma, S.; Sirois, C.M.; Jin, T.; Latz, E.; Xiao, T.S.; et al. IFI16 is an innate immune sensor for intracellular DNA. Nat. Immunol. 2010, 11, 997-1004. [CrossRef]

90. Lo Cigno, I.; De Andrea, M.; Borgogna, C.; Albertini, S.; Landini, M.M.; Peretti, A.; Johnson, K.E.; Chandran, B.; Landolfo, S.; Gariglio, M. The Nuclear DNA Sensor IFI16 Acts as a Restriction Factor for Human Papillomavirus Replication through Epigenetic Modifications of the Viral Promoters. J. Virol. 2015, 89, 7506-7520. [CrossRef]

91. Reinholz, M.; Kawakami, Y.; Salzer, S.; Kreuter, A.; Dombrowski, Y.; Koglin, S.; Kresse, S.; Ruzicka, T.; Schauber, J. HPV16 activates the AIM2 inflammasome in keratinocytes. Arch. Dermatol. Res. 2013, 305, 723-732. [CrossRef]

92. Riva, G.; Pecorari, G.; Biolatti, M.; Pautasso, S.; Lo Cigno, I.; Garzaro, M.; Dell'Oste, V.; Landolfo, S. PYHIN genes as potential biomarkers for prognosis of human papillomavirus-positive or -negative head and neck squamous cell carcinomas. Mol. Biol. Rep. 2019, 46, 3333-3347. [CrossRef]

93. Sun, L.; Wu, J.; Du, F.; Chen, X.; Chen, Z.J. Cyclic GMP-AMP Synthase Is a Cytosolic DNA Sensor That Activates the Type I Interferon Pathway. Science 2013, 339, 786-791. [CrossRef]

94. Wu, J.; Sun, L.; Chen, X.; Du, F.; Shi, H.; Chen, C.; Chen, Z.J. Cyclic GMP-AMP Is an Endogenous Second Messenger in Innate Immune Signaling by Cytosolic DNA. Science 2013, 339, 826-830. [CrossRef]

95. Ablasser, A.; Goldeck, M.; Cavlar, T.; Deimling, T.; Witte, G.; Röhl, I.; Hopfner, K.-P.; Ludwig, J.; Hornung, V. cGAS produces a 2'-5'-linked cyclic dinucleotide second messenger that activates STING. Nature 2013, 498, 380-384. [CrossRef]

96. Uhlorn, B.L.; Jackson, R.; Li, S.; Bratton, S.M.; Van Doorslaer, K.; Campos, S.K. Vesicular trafficking permits evasion of cGAS/STING surveillance during initial human papillomavirus infection. PLoS Pathog. 2020, 16, e1009028. [CrossRef] [PubMed]

97. Chiang, C.; Pauli, E.-K.; Biryukov, J.; Feister, K.F.; Meng, M.; White, E.A.; Munger, K.; Howley, P.M.; Meyers, C.; Gack, M.U. The Human Papillomavirus E6 Oncoprotein Targets USP15 and TRIM25 to Suppress RIG-I-Mediated Innate Immune Signaling. J. Virol. 2018, 92. [CrossRef] [PubMed]

98. Lo Cigno, I.; Calati, F.; Borgogna, C.; Zevini, A.; Albertini, S.; Martuscelli, L.; De Andrea, M.; Hiscott, J.; Landolfo, S.; Gariglio, M. Human Papillomavirus E7 Oncoprotein Subverts Host Innate Immunity via SUV39H1-Mediated Epigenetic Silencing of Immune Sensor Genes. J. Virol. 2020, 94. [CrossRef]

99. Hebner, C.M.; Wilson, R.; Rader, J.; Bidder, M.; Laimins, L.A. Human papillomaviruses target the double-stranded RNA protein kinase pathway. J. Gen. Virol. 2006, 87, 3183-3193. [CrossRef] [PubMed]

100. Kazemi, S.; Papadopoulou, S.; Li, S.; Su, Q.; Wang, S.; Yoshimura, A.; Matlashewski, G.; Dever, T.E.; Koromilas, A.E. Control of $\alpha$ Subunit of Eukaryotic Translation Initiation Factor 2 (eIF2 $\alpha$ ) Phosphorylation by the Human Papillomavirus Type 18 E6 Oncoprotein: Implications for eIF2 $\alpha$-Dependent Gene Expression and Cell Death. Mol. Cell. Biol. 2004, 24, 3415-3429. [CrossRef] [PubMed]

101. Li, X.; Shu, C.; Yi, G.; Chaton, C.T.; Shelton, C.L.; Diao, J.; Zuo, X.; Kao, C.C.; Herr, A.B.; Li, P. Cyclic GMP-AMP Synthase Is Activated by Double-Stranded DNA-Induced Oligomerization. Immunity 2013, 39, 1019-1031. [CrossRef]

102. Diner, E.J.; Burdette, D.L.; Wilson, S.C.; Monroe, K.M.; Kellenberger, C.A.; Hyodo, M.; Hayakawa, Y.; Hammond, M.C.; Vance, R.E. The Innate Immune DNA Sensor cGAS Produces a Noncanonical Cyclic Dinucleotide that Activates Human STING. Cell Rep. 2013, 3, 1355-1361. [CrossRef]

103. Burdette, D.L.; Monroe, K.M.; Sotelo-Troha, K.; Iwig, J.S.; Eckert, B.; Hyodo, M.; Hayakawa, Y.; Vance, R.E. STING is a direct innate immune sensor of cyclic di-GMP. Nature 2011, 478, 515-518. [CrossRef]

104. Hopfner, K.-P.; Hornung, V. Molecular mechanisms and cellular functions of cGAS-STING signalling. Nat. Rev. Mol. Cell Biol. 2020, 21, 501-521. [CrossRef] 
105. Sunthamala, N.; Thierry, F.; Teissier, S.; Pientong, C.; Kongyingyoes, B.; Tangsiriwatthana, T.; Sangkomkamhang, U.; Ekalaksananan, T. E2 Proteins of High Risk Human Papillomaviruses Down-Modulate STING and IFN-k Transcription in Keratinocytes. PLoS ONE 2014, 9, e91473. [CrossRef]

106. Lau, L.; Gray, E.E.; Brunette, R.L.; Stetson, D.B. DNA tumor virus oncogenes antagonize the cGAS-STING DNA-sensing pathway. Science 2015, 350, 568-571. [CrossRef] [PubMed]

107. Bortnik, V.; Wu, M.; Julcher, B.; Salinas, A.; Nikolic, I.; Simpson, K.J.; McMillan, N.A.; Idris, A. Loss of HPV type 16 E7 restores cGAS-STING responses in human papilloma virus-positive oropharyngeal squamous cell carcinomas cells. J. Microbiol. Immunol. Infect. 2020. [CrossRef] [PubMed]

108. Ronco, L.V.; Karpova, A.Y.; Vidal, M.; Howley, P.M. Human papillomavirus 16 E6 oncoprotein binds to interferon regulatory factor-3 and inhibits its transcriptional activity. Genes Dev. 1998, 12, 2061-2072. [CrossRef]

109. Chang, Y.E.; Laimins, L.A. Microarray Analysis Identifies Interferon-Inducible Genes and Stat-1 as Major Transcriptional Targets of Human Papillomavirus Type 31. J. Virol. 2000, 74, 4174-4182. [CrossRef]

110. Nees, M.; Geoghegan, J.M.; Hyman, T.; Frank, S.; Miller, L.; Woodworth, C.D. Papillomavirus Type 16 Oncogenes Downregulate Expression of Interferon-Responsive Genes and Upregulate Proliferation-Associated and NF-kB-Responsive Genes in Cervical Keratinocytes. J. Virol. 2001, 75, 4283-4296. [CrossRef] [PubMed]

111. Hong, S.; Mehta, K.P.; Laimins, L.A. Suppression of STAT-1 Expression by Human Papillomaviruses Is Necessary for Differentiation-Dependent Genome Amplification and Plasmid Maintenance. J. Virol. 2011, 85, 9486-9494. [CrossRef]

112. Wu, S.; Wu, Y.; Lu, Y.; Yue, Y.; Cui, C.; Yu, M.; Wang, S.; Liu, M.; Zhao, Y.; Sun, Z. STAT1 expression and HPV16 viral load predict cervical lesion progression. Oncol. Lett. 2020, 20, 28. [CrossRef] [PubMed]

113. Igelmann, S.; Neubauer, H.A.; Ferbeyre, G. STAT3 and STAT5 Activation in Solid Cancers. Cancers 2019, 11, 1428. [CrossRef] [PubMed]

114. Hong, S.; Laimins, L.A. The JAK-STAT Transcriptional Regulator, STAT-5, Activates the ATM DNA Damage Pathway to Induce HPV 31 Genome Amplification upon Epithelial Differentiation. PLoS Pathog. 2013, 9, e1003295. [CrossRef]

115. Zhang, W.; Hong, S.; Maniar, K.P.; Cheng, S.; Jie, C.; Rademaker, A.W.; Krensky, A.M.; Clayberger, C. KLF13 regulates the differentiation-dependent human papillomavirus life cycle in keratinocytes through STAT5 and IL-8. Oncogene 2016, 35, 5565-5575. [CrossRef]

116. Orecchia, V.; Regis, G.; Tassone, B.; Valenti, C.; Avalle, L.; Saoncella, S.; Calautti, E.; Poli, V. Constitutive STAT3 activation in epidermal keratinocytes enhances cell clonogenicity and favours spontaneous immortalization by opposing differentiation and senescence checkpoints. Exp. Dermatol. 2015, 24, 29-34. [CrossRef] [PubMed]

117. Shukla, S.; Shishodia, G.; Mahata, S.; Hedau, S.; Pandey, A.; Bhambhani, S.; Batra, S.; Basir, S.F.; Das, B.C.; Bharti, A.C. Aberrant expression and constitutive activation of STAT3 in cervical carcinogenesis: Implications in high-risk human papillomavirus infection. Mol. Cancer 2010, 9, 282. [CrossRef] [PubMed]

118. Morgan, E.L.; Macdonald, A. Autocrine STAT3 activation in HPV positive cervical cancer through a virus-driven Rac1-NFkBIL-6 signalling axis. PLoS Pathog. 2019, 15, e1007835. [CrossRef]

119. Morgan, E.L.; Wasson, C.W.; Hanson, L.; Kealy, D.; Pentland, I.; McGuire, V.; Scarpini, C.; Coleman, N.; Arthur, J.S.C.; Parish, J.L.; et al. STAT3 activation by E6 is essential for the differentiation-dependent HPV18 life cycle. PLoS Pathog. 2018, 14, e1006975. [CrossRef]

120. Li, S.; Labrecque, S.; Gauzzi, M.C.; Cuddihy, A.R.; Wong, A.H.; Pellegrini, S.; Matlashewski, G.J.; Koromilas, A.E. The human papilloma virus (HPV)-18 E6 oncoprotein physically associates with Tyk2 and impairs Jak-STAT activation by interferon- $\alpha$. Oncogene 1999, 18, 5727-5737. [CrossRef]

121. LaFleur, D.W.; Nardelli, B.; Tsareva, T.; Mather, D.; Feng, P.; Semenuk, M.; Taylor, K.; Buergin, M.; Chinchilla, D.; Roshke, V.; et al. Interferon- $\kappa$, a Novel Type I Interferon Expressed in Human Keratinocytes. J. Biol. Chem. 2001, 276, 39765-39771. [CrossRef]

122. Rincon-Orozco, B.; Halec, G.; Rosenberger, S.; Muschik, D.; Nindl, I.; Bachmann, A.; Ritter, T.M.; Dondog, B.; Ly, R.; Bosch, F.X.; et al. Epigenetic Silencing of Interferon-k in Human Papillomavirus Type 16-Positive Cells. Cancer Res. 2009, 69, 8718-8725. [CrossRef]

123. Raikhy, G.; Woodby, B.L.; Scott, M.L.; Shin, G.; Myers, J.E.; Scott, R.S.; Bodily, J.M. Suppression of Stromal Interferon Signaling by Human Papillomavirus 16. J. Virol. 2019, 93. [CrossRef]

124. Scott, M.L.; Woodby, B.L.; Ulicny, J.; Raikhy, G.; Orr, A.W.; Songock, W.K.; Bodily, J.M. Human Papillomavirus 16 E5 Inhibits Interferon Signaling and Supports Episomal Viral Maintenance. J. Virol. 2020, 94. [CrossRef]

125. Habiger, C.; Jäger, G.; Walter, M.; Iftner, T.; Stubenrauch, F. Interferon Kappa Inhibits Human Papillomavirus 31 Transcription by Inducing Sp100 Proteins. J. Virol. 2016, 90, 694-704. [CrossRef] [PubMed]

126. Tummers, B.; Goedemans, R.; Pelascini, L.P.L.; Jordanova, E.S.; Van Esch, E.M.G.; Meyers, C.; Melief, C.J.; Boer, J.M.; Van Der Burg, S.H. The interferon-related developmental regulator 1 is used by human papillomavirus to suppress NFkB activation. Nat. Commun. 2015, 6, 6537. [CrossRef] [PubMed]

127. Castro-Muñoz, L.J.; Manzo-Merino, J.; Muñoz-Bello, J.O.; Olmedo-Nieva, L.; Cedro-Tanda, A.; Alfaro-Ruiz, L.A.; HidalgoMiranda, A.; Madrid-Marina, V.; Lizano, M. The Human Papillomavirus (HPV) E1 protein regulates the expression of cellular genes involved in immune response. Sci. Rep. 2019, 9, 13620. [CrossRef] [PubMed] 
128. Ma, W.; Tummers, B.; Van Esch, E.M.; Goedemans, R.; Melief, C.J.; Meyers, C.; Boer, J.M.; Van Der Burg, S.H. Human Papillomavirus Downregulates the Expression of IFITM1 and RIPK3 to Escape from IFN $\gamma$ - and TNF $\alpha$-Mediated Antiproliferative Effects and Necroptosis. Front. Immunol. 2016, 7, 496. [CrossRef]

129. Dunphy, G.; Flannery, S.M.; Almine, J.F.; Connolly, D.J.; Paulus, C.; Jønsson, K.L.; Jakobsen, M.R.; Nevels, M.M.; Bowie, A.G.; Unterholzner, L. Non-canonical Activation of the DNA Sensing Adaptor STING by ATM and IFI16 Mediates NF- $k B$ Signaling after Nuclear DNA Damage. Mol. Cell 2018, 71, 745-760.e5. [CrossRef] [PubMed]

130. Guo, G.; Gao, M.; Gao, X.; Zhu, B.; Huang, J.; Tu, X.; Kim, W.; Zhao, F.; Zhou, Q.; Zhu, S.; et al. Reciprocal regulation of RIG-I and XRCC4 connects DNA repair with RIG-I immune signaling. Nat. Commun. 2021, 12, 2187. [CrossRef]

131. Ranoa, D.R.E.; Widau, R.C.; Mallon, S.; Parekh, A.D.; Nicolae, C.M.; Huang, X.; Bolt, M.J.; Arina, A.; Parry, R.; Kron, S.J.; et al. STING Promotes Homeostasis via Regulation of Cell Proliferation and Chromosomal Stability. Cancer Res. 2019, 79, 1465-1479. [CrossRef] [PubMed]

132. Tigano, M.; Vargas, D.C.; Tremblay-Belzile, S.; Fu, Y.; Sfeir, A. Nuclear sensing of breaks in mitochondrial DNA enhances immune surveillance. Nature 2021, 591, 477-481. [CrossRef] [PubMed]

133. Taffoni, C.; Steer, A.; Marines, J.; Chamma, H.; Vila, I.K.; Laguette, N. Nucleic Acid Immunity and DNA Damage Response: New Friends and Old Foes. Front. Immunol. 2021, 12, 660560. [CrossRef]

134. Iurescia, S.; Fioretti, D.; Rinaldi, M. Targeting Cytosolic Nucleic Acid-Sensing Pathways for Cancer Immunotherapies. Front. Immunol. 2018, 9, 711. [CrossRef]

135. Liu, H.; Zhang, H.; Wu, X.; Ma, D.; Wu, J.; Wang, L.; Jiang, Y.; Fei, Y.; Zhu, C.; Tan, R.; et al. Nuclear cGAS suppresses DNA repair and promotes tumorigenesis. Nature 2018, 563, 131-136. [CrossRef] [PubMed]

136. MacKenzie, K.J.; Carroll, P.; Martin, C.-A.; Murina, O.; Fluteau, A.; Simpson, D.J.; Olova, N.; Sutcliffe, H.; Rainger, J.K.; Leitch, A.; et al. cGAS surveillance of micronuclei links genome instability to innate immunity. Nature 2017, 548, 461-465. [CrossRef] [PubMed] 